\title{
MJ ターンバーの操業経験*
}

三菱製紙株式会社 八戸工場 ○佐藤啓一, 風間邦雄, 山端茂晴

\section{Operating Experience of MJ Turn Bar}

Keiichi Sato, Kunio Kazama and Shigeharu Yamahata

Hachinohe Mill, Mitsubishi Paper Mills Limited

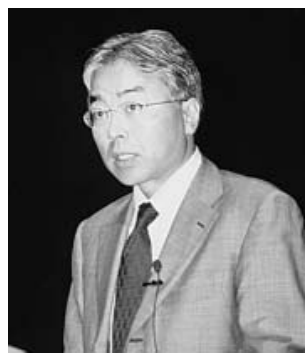

佐藤啓一

Since NO.7 PM (Paper Machine) of Hachinohe Mill, Mitsubishi Paper Mills Ltd. began production in 1997, many kinds of paper products have been manufactured. Especially, woodfree light weight coated paper has such a good quality that the production of woodfree light weight coated paper is dramatically increasing. While we tried to speed up NO.7 PM in order to increase the production, we got a serious problem (release problem) which occurred at the release point of coated paper from the Symsizer ${ }^{\circledR}$ application roll. The release problem caused the unevenness of coated layer and prevented to increase the machine speed.

At last we decided to install "MJ Turn Bar ${ }^{\circledR}$ " to NO.7 PM in order to improve the problem. Then it was already introduced on October 2003 and it's been working well. “MJ Turn Bar ${ }^{\circledR}$ " could make web releasing stability at the release point from the application roll and enable us to increase the machine speed.

In this paper we report about our operating experience of “MJ Turn Bar ${ }^{\circledR}$ " that enabled us not only to keep the quality of woodfree light weight coated paper but also to increase the productivity.

分類： $\mathrm{M}_{1}$ 抄紙・抄紙機一般， $\mathrm{M}_{8}$ サイズプレス

\section{1.はじめに}

当社八戸工場の 7 号抄紙機（以下 7 PM と記す） は, 1997 年に稼働を開始し，コート原紙，上質紙，書 籍用紙, 微塗工紙そして軽塗工紙と多岐に渡る品種の 生産を行っている。軽塗工紙はシムサイザーで塗液を 塗工（両面で約 $14 \mathrm{~g} / \mathrm{m}^{2}$ ) し，そのまま後工程のワイ ンダー, カッターへ送られるオンマシン仕上げの銘柄 で，品質は市場で高い評価が得られており,7 PM の

*平成 16 年度年次大会講演（講演 No. A 14）
生産品種の中でも生産量が飛躍的に増加している銘柄 である。

$7 \mathrm{PM}$ では, 増産・効率向上に向けて日夜努力して いるが, その中でも生産性向上において対策が滞って いるのがこの軽塗工紙の抄造である。増速への取り組 みを阻害する要因の一つとして，シムサイザーのトッ プアプリケータロールに拐ける紙離れ不良により引き 起こされる塗工ムラがある。この塗工ムラは軽塗工紙 抄造の度に状況が全く異なり, 決定的な対策が採れな い状況であった。このトップアプリケータロールから の紙離れの安定化を図る為に, シート裏面からエア圧 
により非接触でシートの走行をサポートする MJ ター ンバー (三菱重工業製) の導入を決定し, 2003 年 10 月より稼働を開始している。

今回は, その MJ ターンバーの操業経験について報 告する。

\section{7 PM の概要}

\section{1 抄造品種}

・品種：コート原紙，上質紙，書籍用紙，微塗工紙， 軽塗工紙

·坪量 : $48 \sim 157 \mathrm{~g} / \mathrm{m}^{2}$

- 抄速: $500 \sim 1,200 \mathrm{~m} / \mathrm{min}$

\section{2 設 備 概 要}

・ヘッドボックス：IHI WA-13500 MJ 型モジュー ルジェット方式スライス币 $5,650 \mathrm{~mm}$

・ワイヤーパート：IHIデュオフォーマD 型

$$
\begin{aligned}
& \text { ワイヤ巾 } \\
& \text { トップ : } 5,850 \mathrm{~mm}
\end{aligned}
$$$$
\text { ボトム：5,800 mm }
$$

・プレスパート：MHI サクションピック+トラ イベント+トランスファーフェルト + ENP-C

・ドライヤーパート：MHI 1 群ベルラン, 2 4 群 ダブルデッキ

・サイズプレス：SHI シムサイザー（スターチ， ピグメント塗工)

・カレンダーパート : MHI ソフトニップカレン ダー, 2 段ロール× 2 スタック

・リーラーパート : SHI オプティリール

\section{3. $\mathrm{MJ}$ ターンバーの導入}

\section{$3.1 \mathrm{MJ}$ ターンバーの概要}

MJ ターンバーはサイズプレス出口に設置し, シー トの走行を下からエアで非接触にサポートする装置で, 主に, $\mathrm{MJ}$ ターンバー本体, 昇降装置, ファン, エア ヒータ, 操作盤, 制御盤により構成されている。図 1 に MJ ターンバー構成の概要を示す。

\subsubsection{MJ ターンバー本体}

$\mathrm{MJ}$ ターンバー本体は, ノズル, バッフル板, 仕切 板，バルクヘッドで構成されている。

ファンより供給されたエアは, バルクヘッドにマシ ン中央部から入り，バルクヘッドからノズルに供給さ れ，ノズル内部で整流される。そして，ノズル上面の 2 本のスリットならびにパンチ穴からエアを吹き出し, シートとの間に空気層を作りシートを浮上させ, シー 卜を接触させることなく搬送する。

ノズル上面に設置されているバッフル板は，シート の入側・出側にエアだまりを設けてシートを確実に浮 上させる目的で，入側・出側に全巾で設置されている。 また，仕切板は巾方向のエアの流れをできるだけ少な くする目的でノズル中央部とバッフル板の両サイドに 設置されている。図2にノズル部分の概要を示す。

\section{1 .2 昇降装置}

昇降装置はジャッキ作動方式で, フレーム, ウォー ムジャッキ, サイクロモータ, クロスシャフト, トル クリミッタ, チェーンならびにスプロケット等で構成 される。

ウォームジャッキのストロークは, トップアプリケ ータロールへのシート抱き長さが約 $200 \mathrm{~mm}$ まで可能

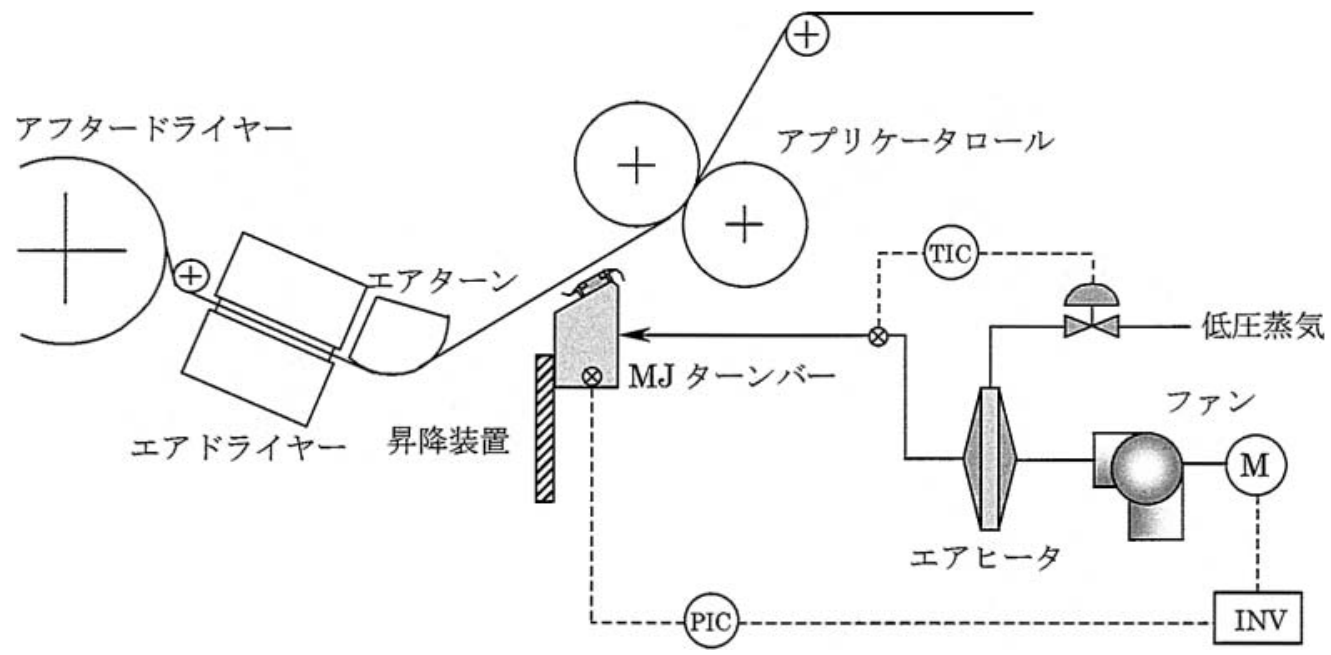

図 1 MJ ターンバー構成概要 


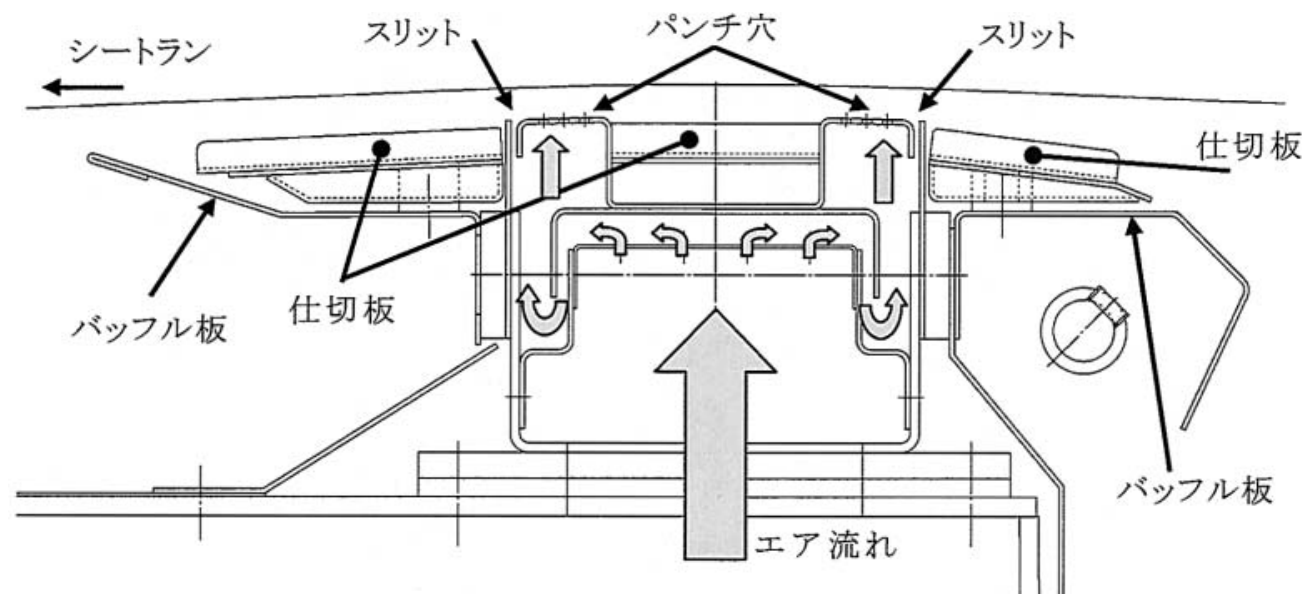

図 $2 \mathrm{MJ}$ ターンバーノズル概要

な仕様となっている。

この昇降装置には, ノズル位置を検出するための位 置検出センサが設置されており, 現在のノズル位置検 出ならびにノズル位置制御に使用される。

昇降装置の暴走防止のため, ストローク上限・下限 位置には近接スイッチが設置され，またその外側には メカニカルストッパを設置して設備保護を図っている。

\section{1 .3 フ ン}

MJ ターンバーのノズルにエアを供給するために使 用され，エアの供給圧力は駆動モーターのインバータ で制御される。

供給圧力は操作盤より任意に設定できるようになっ ている。

\section{1 .4 エアヒータ}

$\mathrm{MJ}$ ターンバー本体の結露防止のため, 供給エアを 昇温するために設置されている。特に乾燥効果が目的 ではなく, あくまでノズルの結露防止効果を狙ってい るため, 昇温されるエアの温度は設計 $60^{\circ} \mathrm{C}$ (MAX) となっている。

\section{$3.2 \mathrm{MJ}$ ターンバー仕様}

・紙市：4, 460 $5,200 \mathrm{~mm}$

・設計速度: $1,300 \mathrm{~m} / \mathrm{min}$

・ファン容量 $: 120 \mathrm{~m}^{3} / \min \times 10 \mathrm{kPa} \times 45 \mathrm{~kW}$ （イン バー夕制御)

・ノズル位置：0８55 mm（シートパスに接する位 置 $757.6 \mathrm{~mm}$ )

\section{MJ ターンバーの設置}

MJ ターンバーは，シムサイザーアプリケータロー ル出口に設置されている。設置工事は事前工事として ソールプレート，ファンならびにエアダクト等の据え
付けに始まり, 本体の設置・調整に約 3 日の工期を要 して行われ, 平成 15 年 10 月 4 日より稼働を開始して いる。

紙離れを安定させるためには, MJ ターンバーの設 置位置はアプリケータニップ出口に近付けるべきであ るが，ニップ下にはアプリケータロール加圧同調用の クロスシャフトがあり, これにより設置位置を制限さ れることとなった。写真 1 に MJ ターンバーの設置状 況を示す。

ノズルの設置角度（シート走行面に対するノズル上 面の角度：平行で $0^{\circ}$ ) は, シートの走行安定性を図 るために, メーカではシート走行面に対して 4 ○アフ タードライヤー側へ傾けるのを推奨としていた。しか し，これはパイロットマシンで抄速 $2,000 \mathrm{~m} / \mathrm{min} ク$ ラスを想定した推奨值である。7 PM の抄速は, 設計 で最大 $1,300 \mathrm{~m} / \mathrm{min}$ であり, $4^{\circ}$ の角度を付ける必要 はないであろうとのメーカ判断により, ノズル角度は $0^{\circ}$ とした。なお，ノズル角度は運転状況により $-2.0^{\circ}$ $\sim+10^{\circ}$ の範囲で調整可能となっている。

\section{5. 操 業 経 験}

\section{1 従来の塗エムラ対策}

塗工ムラは, シートがシムサイザーで塗工されアプ リケータロールニップを出るときに, 本来であればト ップアプリケータロールに抱かれて流れて行くべき所, 瞬間的にボトムロール側に取られることで発生する。 この対応としてアフタードライヤードローを張る, 抄 速ダウン, プレ出口水分増, スチームシャワーの使用 で塗液の粘度を下げる調節をしていた。殆どの場合は アフタードライヤーのドローを張ることで対応できて いたが，過剩なドローの増加は紙切れに繋がることか 
ら好ましい対応ではなかった。

\section{2 操業の実際}

軽塗工紙の抄造において問題となっているのが，前 述したトップアプリケータロールでの紙離れ不良に起 因する塗工ムラの発生である。この対策として，アプ リケータロール径, 硬度, 面粗さ等の様々な面からア プローチしたものの，抄造のその時々により状況の変 化が大きく根本的な解決には至っていないのが現状で あった。この紙離れ不良に対して根本的な解決とはな らないが，シート裏面からエア圧によりトップアプリ ケータロールへの抱きを安定させるべくサポートとし ての役割を狙って導入したのが MJ ターンバーである。

装置そのものは, ノズル高さ，エア圧の調節により シートをフローティングさせる（トップアプリケータ ロールの抱き角を大きくする）だけの非常に簡単なも のである。しかし, 設置例としては 2 例目であり操業 に関する情報も殆ど得られず，まさに手探り状態での スタートとなった。写真 2 に MJ ターンバーの使用状
況を示す。

稼働開始直後はとにかくノズルを高い位置に設定し， エア圧を上げてトップアプリケータロールヘシートを 抱かせさえすれば塗工ムラに対する効果は高いであろ うとの考えで，ノズル位置は 800〜840 mm, エア圧 は通常で $2.3 \sim 4.0 \mathrm{kPa}$, 場合により $8.0 \mathrm{kPa}$ とメー カで想定していた使用範囲を越える領域で使用してい た。しかし，トップアプリケータロールからの紙離れ 安定には決定的な効果とはならなかった。状況の推移 を見ていく中で，ノズル位置，エア圧を高く設定，ま た逆に低く設定した場合でも紙離れには効果が得られ ないことを確認している。この理由としては，ノズル 位置が高く，またエア圧が高いことで，トップアプリ ケータロールからの剥離部以降にエアが集中的に当た ることとなり，ニップ出口付近でのサポート効果が薄 かったものと推定している。また逆の場合も絶対的に エアによるサポートが弱く紙離れ安定に効果が見られ ないのは当然である。
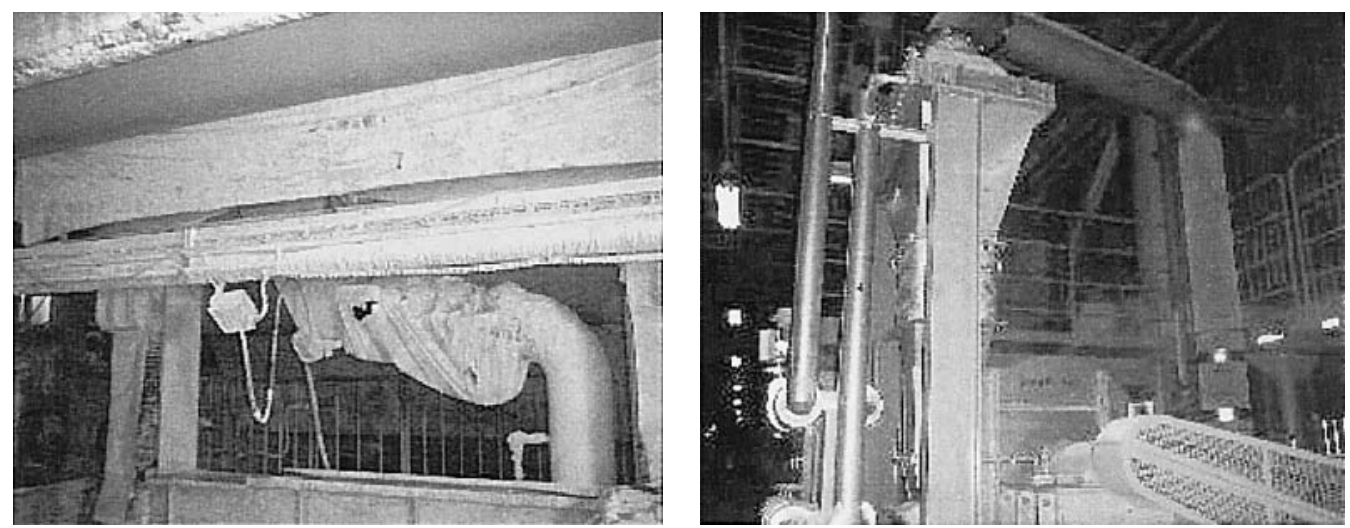

写真 1 MJ ターンバー設置状況
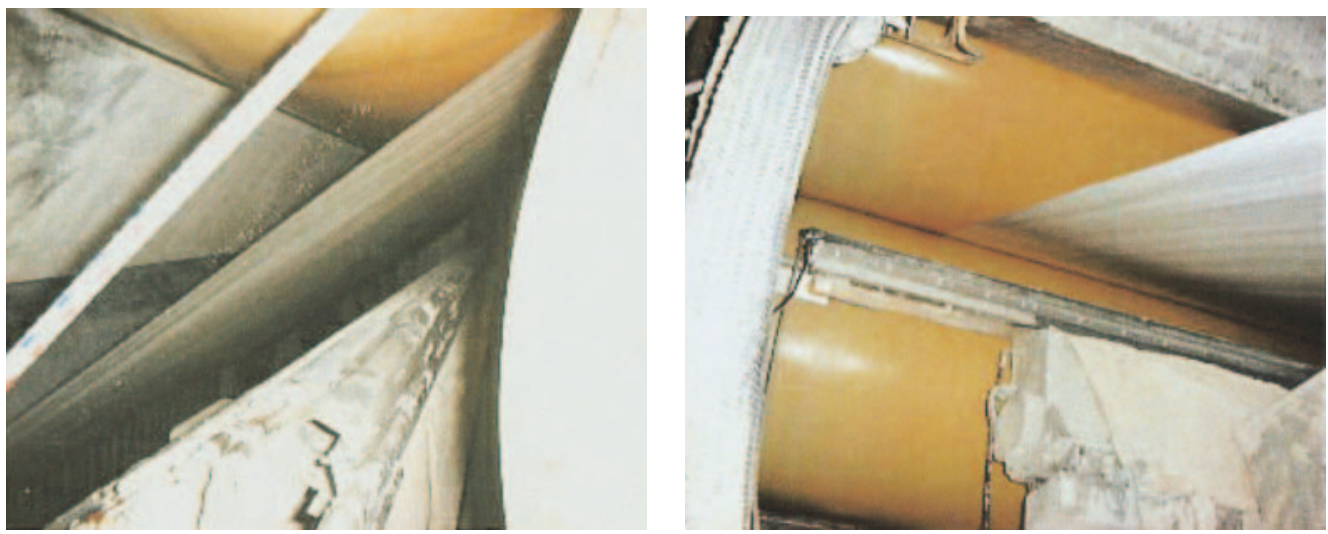

写真 2 MJ ターンバー操業状況 


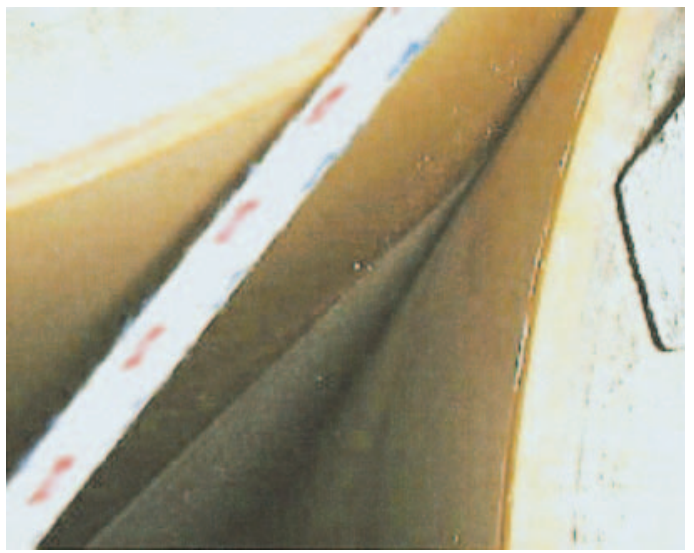

ノズル位置 $550 \mathrm{~mm}$ エア圧 $2.0 \mathrm{kPa}$

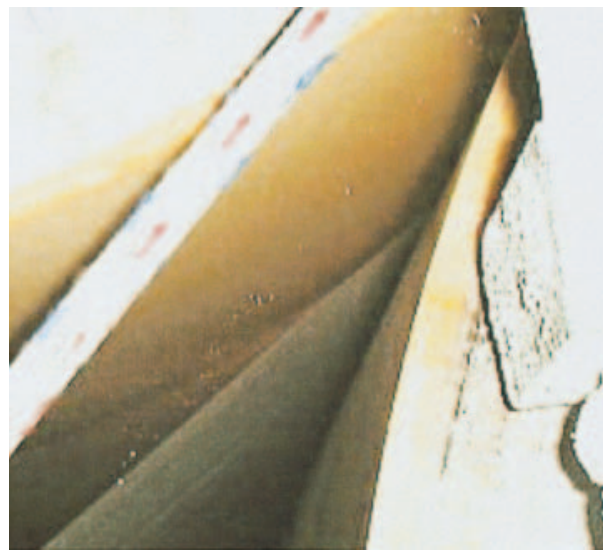

ノズル位置 $700 \mathrm{~mm}$ エア圧 $2.0 \mathrm{kPa}$

写真 3 シート走行性の比較（ノズル位置による比較）

このような経験から, 抄速, 紙離れ状況を確認しな がらノズル位置，エア圧の最適化を模索し，ノズル位 置 600〜 700 mm，エア圧 $2.0 〜 2.3 \mathrm{kPa}$ という条件を 見出して現在に至っている。写真 3 にノズル位置によ るシート走行性の比較を示す。

\section{3 操業で得られた効果}

$\mathrm{MJ}$ ターンバーの導入により, 下記の効果が得られ た。

(1) 紙離れの安定化が図られ, 抄速アップが可能と なった。

(2) 導入前と比較して, アフタードライヤーのドロ 一が安定傾向になった。

(3) 抄速アップにより, 塗工ムラ対策でアフタード ライヤーのドロー増の懸念があったが，抄速アッ プにも関わらず一定レベルで抑えられている。

表 1 に MJ ターンバー導入前後の抄速とアフタード ライヤードローの比較を示す。

図 3 と図 4 に軽塗工紙のメイン坪量である $60.2 \mathrm{~g} /$ $\mathrm{m}^{2}, 64.0 \mathrm{~g} / \mathrm{m}^{2}$ の抄速とアフタードライヤードローの 推移を示す。

$\mathrm{MJ}$ ターンバー導入前の平成 15 年 10 月以前

表 $1 \mathrm{MJ}$ ターンバー導入前後の抄速 · ドロー比較

\begin{tabular}{c|r|c|c|c}
\hline \multirow{2}{*}{ 坪量 $\left(\mathrm{g} / \mathrm{m}^{2}\right)$} & \multicolumn{2}{|c|}{ 抄速 $(\mathrm{m} / \mathrm{min})$} & \multicolumn{2}{c}{ ドロー $(\%)$} \\
\cline { 2 - 5 } & 導入前 & 導入後 & 導入前 & 導入後 \\
\hline 60.2 & 1,005 & 1,080 & 1.39 & 1.39 \\
\hline 64.0 & 1,050 & 1,110 & 1.42 & 1.38 \\
\hline 69.9 & 1,059 & 1,071 & 1.41 & 1.39 \\
\hline 81.4 & 954 & 1,025 & 1.24 & 1.31 \\
\hline
\end{tabular}

は, $60.2 \mathrm{~g} / \mathrm{m}^{2}$ で平均抄速 $1,005 \mathrm{~m} / \mathrm{min}$, ドローは $1.39 \%$ ，また $64.0 \mathrm{~g} / \mathrm{m}^{2}$ では平均抄速 $1,050 \mathrm{~m} / \mathrm{min}$, ドロー $1.42 \%$ であった。これに対して, 導入後の平 成 15 年 10 月以降では, $60.2 \mathrm{~g} / \mathrm{m}^{2}$ で平均抄速 $1,080 \mathrm{~m}$ $/ \mathrm{min}$, ドロー $1.39 \%, 64.0 \mathrm{~g} / \mathrm{m}^{2}$ で平均抄速 $1,110 \mathrm{~m} /$ $\min$, ドロー $1.38 \%$ と抄速アップの効果と, 僅かで はあるがドロー緩和の効果が見られている。グラフを 見ても判るように，特に $64.0 \mathrm{~g} / \mathrm{m}^{2}$ では諸条件による 塗工ムラの対応に追われ安定的なドローが得られてい

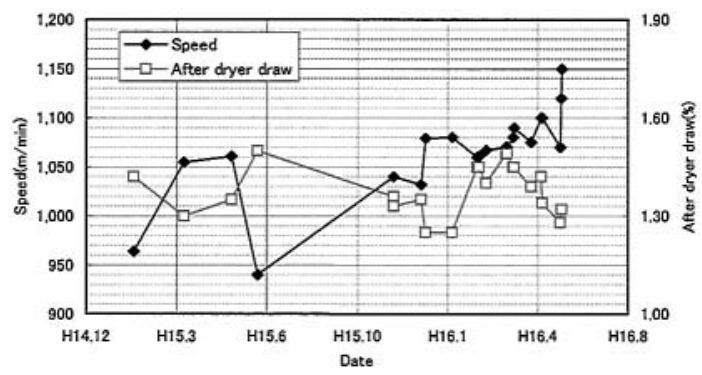

図 3 軽塗工紙 $60.2 \mathrm{~g} / \mathrm{m}^{2}$ 抄速, アフタードライヤ ードロー推移

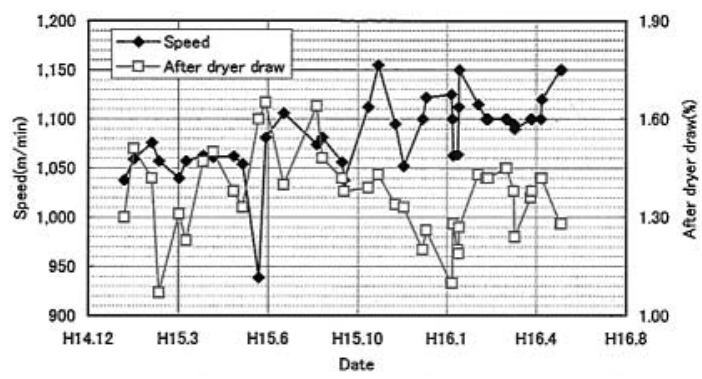

図 4 軽塗工紙 $64.0 \mathrm{~g} / \mathrm{m}^{2}$ 抄速, アフタードライヤ ードロー推移 
なかったが，導入後はドローの変動も少なく，低めの 設定で対応できるようになり工程も安定した。平成 16 年 1 月頃を境にドローが増加傾向にあるのは, 品 質対応（面質，表裏差対応）によりシムサイザーでの 塗工条件が変わったためである。

平均值で見ると上述の通りであるが，平成 16 年 5 月抄造時には, 雨坪量とも当面の目標としていた抄速 $1,150 \mathrm{~m} / \mathrm{min}$ での製造を行っており, 品質・操業面 で特に問題は見られていない。

\section{4 現状における問題点}

$\mathrm{MJ}$ ターンバーの導入により, 抄速が上がり生産性 向上に一定の効果が得られたが，その一方で現状で抱 えている問題点について述べる。

従来から，アプリケータロールニップ出口から発生 する塗液のミストは見られていたが, MJ ターンバー の導入後, MJ ターンバーを含めたシムサイザー周辺 の污れが顕著に現れてきた。これは，もともと塗液が 紙巾より広い巾でアプリケータロールに転写している ため端部からミストが発生することに加えて, MJ 夕 ーンバー導入によりニップ出口周辺で気流の雲囲気が 変化したことで, 発生したミストを飛散させてしまっ ていることに原因がある。このミストでトップ側セー ヴォール，キャリアホイルそして MJ ターンバー両サ イドを污す結果となっている。また，ミストの発生は
抄速が上がる程に発生量の増加が著しく, 抄速アップ がミスト污れを助長している点もある。ミスト污れの シートへの跳ね込みや落下により, カレンダーで型欠 点が発生するため, その対策としてキャリアホイル撤 去, また MJ ターンバーへエアパージを設置し型欠点 に対する効果を上げた。しかし，ミスト污れそのもの には対処しきれて抢らず，操業中のミスト污れ掃除を 強いられている状況であり, 今後の抄速アップならび に効率向上に向けて重要な課題である。

\section{6. おわりに}

以上の通り, $7 \mathrm{PM}$ での $\mathrm{MJ}$ ターンバーの操業経験に ついて報告した。

従来は生産性の上がらなかった軽塗工紙の抄造にお いて, MJ ターンバーを適用することで, 品質を確保 しつつ生産性を向上させることができたと考える。今 後は, 現状抱えている問題点に対して一つ一つクリア にしながら，今後高まるであろうユーザの要求への対 応と生産性を両立させるべく, 操業条件の確立を図っ ていく考えである。

最後に本設備の設置, 操業に関してご指導, ご協力 頂いた三菱重工業(株ならびにシムサイザー本体部分の 污れ対策にご助言頂いたメッツォSHI(秼をはじめとす る関係各位にこの場をお借りして御礼申し上げる。 